\title{
ASCLEPIUS \\ CONTRIBUTION TO ASCLEPIUS' EGYPTIAN RELATION
}

Summary: The Hermetic dialogue Asclepius occupies a central place in the Corpus Hermeticum. One part of Asclepius and the prayer at its end was translated into Coptic from Greek. This paper examines the richness of Egyptian thought incorporated into the dialogue and demonstrates the close relations between the work and Hellenistic Egyptian religion.

Key words: Asclepius, Corpus Hermeticus, its Coptic version, Hellenistic Egyptian religion.

The Asclepius dialogue is the Latin version of a Greek hermetic writing that was considered to be the summit of the Corpus Hermeticus. In Greek it was entitled logos teleios, the Perfect Dialogue. ${ }^{1}$ The dialogue belongs to the Greek literary tradition of the discussion that took the form of a dialogue without unfolding a real dispute. Generally, it is the master of the dialogue himself who raises the fundamental questions.

The dramatis personae are Hermes Trismegistus, Asclepius, Tat, and Hammon. Hermes is the threefold great god, the paraclitus of the Gospel according to St John, ${ }^{2}$ the visible representative of the divine world. He directs the dialogue explaining the inherence of the universe to Asclepius. The Egyptians revered the Greek healing god Asclepius under his Graeco-Egyptian name, Imouthes. He is the only one who piously

${ }^{1}$ For an essential treatment of the Corpus, see Nock, A. D.-FESTUGIÈRE, A.-J.: Corpus Hermeticum, tome I-II. ${ }^{2}$ Paris: Les Belles Lettres, 1960; for the Logos teleios, cf. NocK-FESTUGIÈRE: Corpus Hermeticum I, 264-275. St Augustine, Pseudo-Augustine and Lactantius, later St Cyrillus, Stobaius and Joannes Lydus quoted from the Logos. Interest in the Hermetica evolved in the 11 th century $A D$, and was especially strong in the 12 th century. For the Latin version of the Logos, see NOCK-FESTUGIĖRE: Corpus Hermeticum I, 296-355. The Logos was partially translated into Coptic in the 4th century AD. This was included in the gnostic library found at Nag Hammadi in 1949. MAHE, J.-P.: Hermès en Haute-Egypte II. Bibliothèque copte de Nag Hammadi, section: «Textes», 7. Quebec, Canada: Les presses de 1'Université Laval, 1982, 152-207, presented the Coptic version together with the Latin text and Greek fragments. BRASHLER, J.-DIRKSE, P. A.-PARROTT, D. M. in: The Nag Hammadi Library in English ${ }^{3}$. Ed. by J. M. Robinson. New York-Köln-Københaven: Brill, 1988, 330-331, offers a modern English translation of the Latin and Coptic versions. For the Egyptian relation of Hermetism, see FowDEN: G.: The Egyptian Hermes. A Historical Approach to the Late Pagan Mind ${ }^{2}$. Princeton, NJ: Princeton University Press, 1993.

${ }^{2}$ John 14: 16, 26; 15:26; 16: 7: the explanation of the Holy Spirit. 
listens to Hermes. He occasionally poses a question that is unnecessary for the progress of the discourse. However, he is the pupil of Hermes. Unlike him, the third and fourth actors, Tat and Hammon, do not display a marked character. They only receive a short estimation at the beginning of the tract, when Hermes says: "Nous ne sommes si jaloux, dit Trismegiste, que d'écarter Hammon de notre groupe; car, il m'en souvient, beaucoup de mes écrits lui ont été dédiés, comme aussi à Tat, mon fils très aimant et très cher, beaucoup de mes traités physiques et une foule d'ouvrages 'du dehors',",

Hermes Trismegistus is of Egyptian origin, a fact acknowledged since John Ray had pointed out the epithet in the Demotic material from Saqqara. ${ }^{4}$ A Greek inscription of $75 \mathrm{BC}$ contains three omegas and the Egyptian Thoth's common epithet, NOB ZMOYN, Ashmunein, the master of Hermupolis. ${ }^{5}$ The three $\tilde{\omega} \mu \varepsilon \dot{\varepsilon} \gamma \alpha$ could

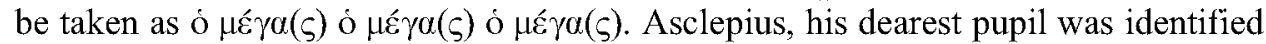

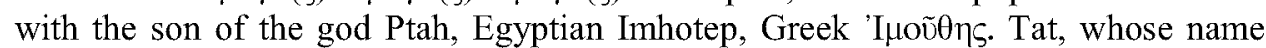
seems to be an unstressed form of the god Thoth, appears as Trismegistus' beloved son. We know practically nothing about Hammon whom scholars, following Walter Scott, have linked with a royal person. A possible solution to the question could be to identify him with Ammon of Siwa, despite the spiritus asper that is present in the form Hammon. Particularly Greeks and peoples of other origin worshipped him in the Hellenistic period in particular as indicated by Alexander's journey to the Siwa oasis. The Coptic translation omits the laryngeal ' $h$ ' sound. ${ }^{6}$ The shape of the names indicates that the gods are not of pure Egyptian origin; they reveal rather Hellenistic forms.

Scholars of the Renaissance believed that the corpus hermeticum contained the secret Egyptian wisdom that especially certain writers of the Roman period referred to. Thus, when a manuscript of the corpus hermeticum was brought to Florence in 1463, the Neoplatonic philosopher Marsiglio Ficino interrupted his translation of Plato and immediately set about translating the corpus. This was an excellent occasion to decipher this desired source of wisdom. ${ }^{7}$

The great Greek philosophers were believed to have obtained their real knowledge in Egypt. Herodotus mentioned that Thales had an eastern ancestry. ${ }^{8}$ According to Aristotle it was Thales, one of the seven sages, who established the science of physics. His eastern origin makes it probable that he incorporated Egyptian and Near Eastern ideas into his cosmology.

Plato, the most influential thinker of the post-classical period left Athens for six years after the execution of Socrates. He appears to have travelled in the Oi-

${ }^{3}$ Translated by A.-J.FeSTUGIÈRE, in: Corpus Hermeticum, 297.

${ }^{4}$ RAy, J. D.: The Archive of Hor. Texts from Excavations 2. London: EES, 1976, 159-160. Cf. KÁkOSY, L. in: Studies in Pharaonic Religion and Society in Honour of J. Gwyn Griffiths. London: EES, 1992, 258-261.

${ }^{5}$ GIRGIS, V. in: MDAIK 20, 1965, 121.

${ }^{6}$ This is not decisive, but simply noteworthy. It appears, however, that the Greek spiritus lenis was marked by the laryngal ' $h$ ' sound.

${ }^{7}$ See ASSMANN, J.: Agvpten - eine Sinngeschichte. München-Wien: Hanser, 1996, 478, and RUDOLPH, K.: Die Gnosis. Leipzig: Koehler und Amelang, 1977, 31

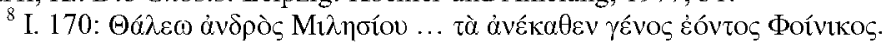


kumene and in Egypt. He refers to Egypt in the dialogues in a manner to suggest that he was familiar with Egyptian customs. This effect contributed to the emergence of a tradition that Plato had spent several years in Egypt. ${ }^{9}$ In fact, Plato speaks about Egyptian education and Egyptian laws with appreciation in the dialogue Laws.

Born in the North African town of Madaurus, Apuleius lived in 2nd century AD. He was an erudite man of wide-ranging interests who wrote novels and tracts on Platonic philosophy, one of the reasons he is considered to belong to Middle Platonism. When using the Isis mystery in Book IX of his Metamorphoses, he revealed a definite attitude towards Hellenic Egyptian cults. Later, in the Middle Ages, the Asclepius dialogue was added to his work without title and author, ${ }^{10}$ but similarly to earlier scholars, Alanus ab Insulis accepted Hermes Trismegistus as an individual philosopher. ${ }^{11}$

The tradition of the Asclepius text is special. Only the Latin version has survived, even though it was the Greek version that was always believed to be the genuine one. The Latin translation was for some time attributed to Apuleius, but St Augustine quoted from this work in one of his treatises on idolatry using a Latin version. ${ }^{12}$ Pseudo-Augustine quoted from a Greek version that was also known to Lactantius as shown by his Divinae Institutionis. ${ }^{13}$ The Greek magical papyrus Mimaut was written around $300 \mathrm{AD}$; here the Egyptians included the closing prayer of Asclepius. ${ }^{14}$ Hence the Latin and Greek versions of Asclepius were known towards the end of the 3rd century. The Latin translation of Asclepius definitely proves the widespread diffusion of the dialogue in the Greek and Latin-speaking world. The acceptance of Hellenistic Egyptian cults and relicts of Egyptian culture in Rome may plausibly explain the necessity of the Latin translation.

A Gnostic community had flourished in Upper Egypt since the 2nd century AD. We had to look for the Coptic translator of that particular part of Asclepius that rather refers to Egypt, but the part also reflects general hermetic thoughts. I would not stress the difference between Gnostic and hermetic thought as most scholars usually do. ${ }^{15}$ The selection starts with the sexual intercourse of a human couple, but affection (caritas), pleasure (laetitia), joy (hilaritas), desire (cupiditas) and love (amor) are gifts of the creator god according to the discourse. Hence the couple secretly enjoys these divine gifts.

${ }^{9}$ See KÁKosy, L., in: Gedenkschrift István Hahn (Annales. Sectio historica, t. XXVI). Budapest, 1993, 25-28; cf. SHOUCRI, R. M., in: Ägypten und Nubien in spätantiker und christlicher Zeit. Sprachen und Kulturen des christlichen Orients 6. Wiesbaden: Reichert, 1999, 522.

${ }^{10}$ See Nock, in Nock-FesTUGIĖRE: Corpus Hermeticum I, 277; further Friedrich Ueberwegs Grundriss der Geschichte der Philosophie, vol.II: Die patristische und scholastische Philosophie ${ }^{13}$ Darmstadt: Wissenschaftliche Buchgesellschaft, 1958, 149. The dialogue is labeled as Pseudo-Apuleius.

${ }_{11}^{11}$ See Ueberwegs Grundriss II, 246

${ }^{12}$ Corpus Hermeticum I, 264-265.

${ }^{13}$ Corpus Hermeticum I, 266.

${ }^{14}$ PGM III 591-609, col. XVIII.

${ }^{15}$ RUDOLPH, K.: op. cit. (note 7) 291-304; FoWDEN, op. cit. (note 1), 31-44. 
The Coptic translator did not possess a philosophical word-stock similar to the Greek or Latin speakers. ${ }^{16}$ This kind of vocabulary had never developed in Egypt, although Hungarian research made an effort to print out the Egyptian philosophy. ${ }^{17}$ These efforts were not particularly successful since Egypt evolved a religious vocabulary that confronts every researcher interested in Egyptian religion with tasks that practically cannot be answered. ${ }^{18}$ Egyptian religious expressions are full of delicate nuances that we are unable to interpret in the proper way. The realm of pagan religion maintained much of the ancient religious vocabulary, but the Christian literature also shows this feature.

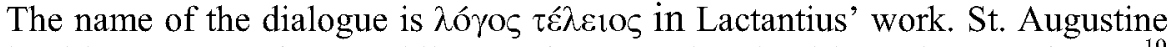
used the title sermo perfectus, while Pseudo-Augustine the title verbum perfectum. ${ }^{19}$ The original Greek title of the dialogue reveals that Asclepius contains the main features of Hermetism. Arthur Darby Nock, editor of the Latin text pointed out that each theme has its counterpart in a parallel text. This supports the importance of Asclepius within the corpus hermeticum. Nock discovered three guiding principles:

1. The one and the many;

2. god, universe, and man;

3. revelation, piety, and clemency.

Egyptian wisdom contributed to almost all religious themes in Hellenistic times. Its competence was widely accepted in the opinion of Greek authors since Herodotus. He was the first whose reference to Egyptian religious ideas endured, but he was not the first to write about Egyptian religion. His claim that Egyptians "are religious to excess, beyond any other nation in the world", ${ }^{20}$ echoes the Asclepius where the topic is transferred to Egypt, but I believe it is the same.

The author of Asclepius appears to speak of Egypt in an extreme manner. On one hand the country is a paradise on Earth, on the other she is the scene of a cataclysmic catastrophe. Trismegistus expresses the first thought in the following way: «Or are you ignorant, Asclepius, that Egypt is (the) image of heaven? Moreover, it is

\footnotetext{
${ }^{16}$ In this part the Latin text differs from the Coptic one:

denique eo tempore ex commixtione cummuni et virtutem feminae marum adipiscuntur et

en ce point donc tu constate que, par une mélange entre les deux natures, et la femme se pourvoit de la vigueur du mâle et

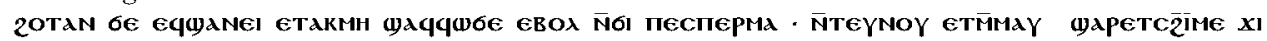
$\overline{\mathbf{N}}$ ToOM $\overline{\mathrm{M}} \phi 00 \gamma \mathbf{T}$

When the man arrives at the peak, the sperma ejaculates. In this moment the woman receives the virile force,

mares femineo torpore lassescunt.

le mâle se détend en féminine langueur (tr. by A.-J.Festugière).

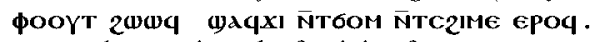

a man also receives the feminine force.

${ }^{17}$ See DoBRoviTs, A., in: Egyiptom és az ókori Kelet világa. Budapest: Ókori Történeti Tanszékek, 1975, 531 .

${ }_{18}$ AsSManN, J.: Ägypten. Theologie und Frömmigkeit einer frühen Hochkultur ${ }^{2}$. Stuttgart: Kohlhammer, 1991, 7-8.

${ }^{19}$ See Corpus Hermeticum I, 276-277. 143.

${ }^{20}$ II. 37, translated by SELINCOURT, A. de, in: Herodotus. The Histories. Penguin-Books, 1973,
} 
the dwelling place of heaven and all forces that are in heaven. $\rangle^{21}$ The author attaches the contrary vision immediately to the first thought: «And it is proper for you not to be ignorant that a time will come in it (our land when) Egyptians will seem to have served the divinity in vain, and all their activity in their religion will be despised. For all divinity will leave Egypt and will flee upward to heaven. And Egypt will be widowed; it will be abandoned by the gods. For foreigners will come into Egypt, and they will rule it.» ${ }^{22}$ The end of the pious Egypt is quite definite, not because of foreign invaders, but because the Egyptians themselves abandoned the fervour of piety. All parts are Egyptian commonplaces:

1. Since Dynasty XVIII Egyptians have formulated the idea that the gods leave Egypt for the sky; ${ }^{23}$

2. Syria will be a widow when Egyptians ravage her, performing Amun's wish as a Ramesside stela reports; ${ }^{24}$

3. Egyptians should take care of the cults in order to prepare the dwelling places for the gods, not to receive something from the gods. This thought has been expressed during the pharaonic era several times. ${ }^{25}$

One of the main themes of the dialogue is the so-called cult of idols. This theme is only comprehensible from a Jewish-Christian perspective. The cult of idols is utterly condemned in the Old Testament. The Hellenistic Book of Wisdom, being last in a long tradition, put it in the following way: «But what is made with hands is accursed, along with the man who made it, because he shaped it, and what was perishable was called a god. For the ungodly man and his ungodliness are equally hateful to God» ${ }^{26}$ Christians used to deny the worshipping of idols.

The Egyptian cult of statues developed in the 3rd millennium BC and survived for three thousand years. Egyptians did not even glimpse the cult statues that rested usually in barks in the chapel. The high priest was the only person who, as representative of the king, could approach the statue without harm. According to the unpublished Book of the Temple from the Ptolemaic period, the high priest should approach the statue showing his back to it. He should open the door of the chapel in this position.

The Egyptians of the Roman and Byzantine period were afraid of all works of art because they were believed to be living beings. Indeed, statues and other works of art were vessels prepared as the gods' dwelling place (descensio) when they descended from the sky to dwell among people. Then Egypt served the real dwelling

${ }^{21} N H$ VI 70 (4)-(7), translated by BRASHLER, DIRKSE and PAROTT, in: The Nag Hammadi Library $^{3}, 334$

${ }^{22} N H$ VI 70 (10)-(21), translated by BRASHLER, DIRKSE and PAROTT, in: The Nag Hammadi Library $_{23}^{3}, 334$. recht, 1982

HoRNUNG, E.: Der ägyptische Mythos von der Himmelskuh. Göttingen: Vandenhoeck \& Rup-

${ }^{24} K R I$ IV 19 (7) translated by NicCACCI, A., in: Études Égyptologiques et Bibliques à la mémoire du Père B.Couroyer. Paris: Gabalda, 1997, 64.

${ }^{25}$ See ASSMANN, op. cit. (note 18), 35-50.

${ }^{26}$ Sap 14: 8-9, translated by GoODSPEED, E. J.: The Apocrypha. Random House, 1959. 
place of gods as it was stressed in the dialogue. Egyptians were uncertain about the date of the gods' arrival and departure from Egypt. ${ }^{27}$

To understand the concept of statue in Hellenistic times, we can refer to the Canopic decree of $238 \mathrm{BC}$. The Egyptian priests assented to the cult of the Macedonian kings in Egypt, as to the cult of Ptolemy II Euergetes and his wife Berenike. ${ }^{28}$ They venerated their dead daughter Berenike with statues in the temples of the first and second class. ${ }^{29}$ In this way they maintained the memory of the princess with offerings too, though her parents also received offerings. Imperator Julian Apostate who possibly knew the impotence of statues offered the sun as $\zeta \widetilde{\omega} v \alpha \gamma \alpha \lambda \mu \alpha$, "living image' to the Alexandrians. ${ }^{30}$ The Greek expression $\alpha \gamma \alpha \lambda \mu \alpha$ discloses the significance of the image in this context. The lexeme $\alpha \gamma \alpha \hat{\lambda} \mu \alpha$ has a special connotation because the meaning of the verb is rather to honour. ${ }^{31}$

The images of Egyptian gods were living and powerful. In this connection I would like to refer to the healing statues of gods whose fame also spread abroad. The so-called Bentresh stela, probably dating to the last third of the 4th century BC, contains a story from the Ramesside period. ${ }^{32}$ The prince of Bactria, father-in-law of King Ramses II, asked for help from the king. The sister-in-law fell ill in Bactria. The king was asked to send a healing statue to cure her. The Egyptian king consulted with the god Khonsu of Thebes who sent his son Khonsu, Performer of the Plans of the Great God. The success of the god's statue was so overwhelming in Bactria that they did not want to return the statue to Egypt. However, it became apparent that the statue could only exert its power in Egypt. Thus, finally, the statue was sent back.

The Egyptians had several words for the statue, depending on its purpose. The Demotic language kept only one word, twt.w, the common word of the elder language, known from the name Tutankhamun, "Living image of Amun". 33 This does not mean that the king put on the god's image, but the god has chosen the king as his temporary dwelling place. Hence $t w t . w$ is not the real feature of the god, but the

${ }^{27}$ OCKINGA, B.: Die Gottebenbildlichkeit im alten Ägypten und im Alten Testament. ÄAT, 7. Wiesbaden: Harrassowitz, 1984, 18. A statue is a substitute and the double of a god or the god like dead. The gods may occupy substitutes of all kinds, cf. ASSMANN, op. cit. (note 18), 53, where he uses the expression descensio. The Egytian concept of divine shapes is quasi defined in Memphitic Theology (56)-(57).

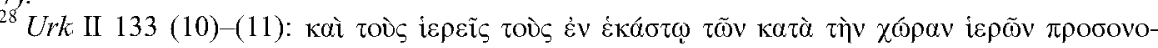

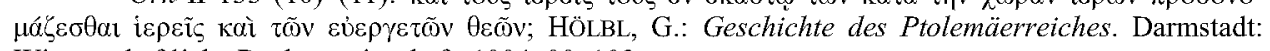
Wissenschaftliche Buchgemeinschaft, 1994, 99-103.

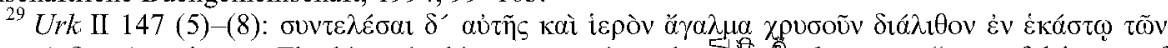
$\pi \rho \omega \tau \omega \mathrm{v} \kappa \alpha \grave{\imath} \delta \varepsilon v \tau \varepsilon \rho \operatorname{\varepsilon } \rho \mathrm{i} \varepsilon \rho \tilde{\omega} \mathrm{v}$. The hieroglyphic text mentions the god", which corresponds to the Greek icpòv ă $\gamma \alpha \lambda \mu \alpha$.

${ }^{30}$ LEIPOLDT, J.: Der römische Kaiser Julian in der Religionsgeschichte. SbLeipzig 110/1. Berlin: Akademie, 1964, 14

${ }^{31}$ See LIDDELL-SCOTT: "glory, honour, a pleasing gift, a statue in honour of a god, an image, any statue, also a portrait, picture", the latter at Platon. The meaning "statue" dates to the post-classic period.

${ }^{32}$ KRI II 284-287; SPALINGER, A., in: SSEAJ 8, 1977-78, 11-16.

${ }^{33}$ Hornung, E., in: Die Gottebenbildlichkeit des Menschen. München, 1964, 123-156; for twt.w, cp. 144-145. EATON-KRAUSS, M.: The Representations of Statuary in Private Tombs of the Old Kingdom. ÄgAbh 39. Wiesbaden: Harrassowitz, 1984, 77-83, discusses the context and the origin of the word. Cf. also GOEDICKE, H., in: GM 134, 1993, 41-54. 
presence of his character. Shortly, the praesentia dei corresponds to the concept of twt.w.

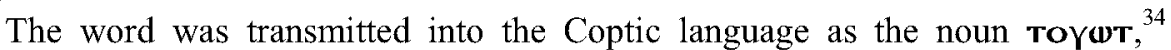
meaning 'idol, pillar'. The latter recalls the stone memorials of the Old Testament. Tattam gave a third meaning as chapel or temple that occurs in the Acts of the New Testament. The word also appears as a verb, TooyTe, meaning 'to gather'. Surely, all meanings reveal the significance praesentia. ${ }^{35}$

This word appears in the logos teleios when Hermes Trismegistus explains the production and veneration of idols to his pupil. The meaning of the word might not have been clear to the pupil, and thus Hermes answered the question of his pupil ${ }^{36}$ by explaining the meaning: "You say about those who have soul and breath that they are idols - those who bring about these great events. You are saying about those who give prophecies that they are idols - these who give [men sickness and] healing that $[\ldots]$ them." 3

The Latin text reflects the same idea, but dropped the second person: statuas animatas sensu et spiritu plenas tantaque facientes et talia; statuas futurom praecias easque sorte, vate, somniis multisque aliis rebus praedicentes, inbecillitates hominibus facientes easque curantes tristitiam laetitiamque pro meritis. This is not the place to discuss the concept of the Latin statue, but one could state that the concept has a narrower sense as compared to the Egyptian concept.

The word тоүшт scarcely appears in Coptic texts. The Egyptians used the Greek loan-word čik $\omega v$ for depiction, as it is used in present times. ${ }^{38}$ This word appears in all Christian texts. On the contrary, the use of the Egyptian word in a pagan text is conspicuous, as though this concept needs to be explained in this late period.

To sum up, Asclepius displays several concepts the Egyptian origin of which can hardly be denied. Especially this hermetic text has an Egyptian taste what could be extended to all hermetic writings. The character of Hellenism allows the conclusion that Egypt, as one of the most pious countries, has contributed to the development of new religious concepts to a great extent.

Department of Egyptology

Eötvös Loránd University

$\mathrm{H}-1088$ Budapest

Múzeum krt. 4/B

${ }^{34}$ TATTAM, H.: Lexicon Aegyptiaco-Latina. Oxonii, 1835, 530; CD 447b.

${ }^{35}$ I have discussed this problem in: Acta Ant. Hung. 40, 2000, 283-310.

${ }^{36}$ Ascl. 24: statuas dicis, o Trismegiste. The Coptic version has undoubtly a question, NHC VI 69

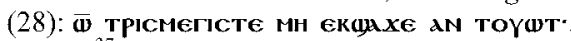

${ }^{37} \mathrm{NHC}$ VI 69 (32)-70 (2).

${ }^{38}$ BöHLIG, A.: Studien zur Erforschung des christlichen Aegyptens, vol. 2. München: Lerche, $1954,311-312$. 